\title{
UTILIZATION OF SOLAR ENERGY FOR IMPROVING BIOGAS PRODUCTION FROM FARM DIGESTERS Youssef, G.D.M. ${ }^{1}$ and M.K. EL-bakhashwan' ${ }^{2}$ \\ ${ }^{1}$ Hort. Res. Inst., Agricultural Research Center \\ 2 Agric. Eng. Res. Inst., Agricultural Research Center.
}

\begin{abstract}
A solar water heater system has been built and installed at a farm scale operated digester of dairy cows wastes. The solar heating system (solar collectors and storage tank) is connected to a heat exchanger situated inside the digester in order to provide and maintain the wastes temperature at the mesophilic temperature range $\left(37^{\circ} \mathrm{C} \pm 2\right)$. Over sixty one days the solar heating system collected $3135 \mathrm{kWh}$ of heat energy. The obtained results showed that, the contribution percentages of the solar heating system were 65.30 and $51.61 \%$ and the error root mean square in predicting the digester temperature was 1.66 and $1.83^{\circ} \mathrm{C}$ in cold winter months November and December, respectively. While the total biogas production rate and net energy production were increased by $71.4 \%$ and $24.1 \%$, respectively.
\end{abstract}

\section{INTRODUCTION}

The rise in oil and natural gas prices may drive the current economy toward alternative energy sources such as biogas. It is one of the most promising uses of biomass wastes because it provides a source of energy while simultaneously resolving ecological and, agrochemical issues. Thus, research on various aspects of biogas production has become important for it widespread utilizations. One of the important aspects is the heat requirement for the digester. In recent years, production of biogas by anaerobic digestion method has been reconsidered as an alternative means for producing clean fuel (Alvarez and Lide'n, 2008). The process of anaerobic digestion has the potential of converting biodegradable organics into biogas which comprises methane $(55-75 \%)$ and carbon dioxide $(25-45 \%)$ and traces of $\mathrm{H}_{2} \mathrm{~S}(<0.5 \%)$ (Steffens et al., 2000). The anaerobic digestion is sustainable option for biowaste management and it produces valuable biogas to replace fossil fuels in various technical applications (Basrawi et al., 2010 and Kymäläinen et al., 2012). Biogas can therefore be a source of energy for developing countries especially in this era of insecurity and unpredictability in fossil fuel supply.

The breakdown of organic materials usually occurs in three temperature ranges: the psychrophilic $\left(12-30^{\circ} \mathrm{C}\right)$, mesophilic $\left(25-40^{\circ} \mathrm{C}\right)$ and thermophilic $\left(45-60^{\circ} \mathrm{C}\right)$. But anaerobic digestion is mainly taking place at either mesophilic, or thermophilic temperatures (Song et al., 2004, and Kim et al., 2006). Choorit and Wisarnwan (2007) revealed that, the temperature of digestion process is an important parameter that modifies the effectiveness of the anaerobic bacterial consortium to produce methane from organic matter. They also, concluded that, the $37^{\circ} \mathrm{C}$ reactor could tolerate temperature variations in the range of $37-43^{\circ} \mathrm{C}$ without significant changes in an index for process stability.

Manik et al., (1994) discovered that, the maximum biogas production with enriched methane content $(62 \%)$ was achieved with retention time of ten days at $40^{\circ} \mathrm{C}$, while Graaff et.al., (2010) found out that, the maximum production of biogas from cow dung was at thermophilic temperature. 
Therefore, temperature is a very important parameter to be considered for designing of the biogas generation. Moreover, Vindis, et. al., (2009) showed that, the temperature of anaerobic fermentation in the mesophilic and thermophilic range had effect on the yield of biogas from maize. Usman et al., (2012) investigated the effect of temperature on biogas generation from maize chaff and maize chaff blended with poultry droppings, three different temperatures of $30^{\circ} \mathrm{C}, 45^{\circ} \mathrm{C}$ and $60^{\circ} \mathrm{C}$ in batch anaerobic digesters were functioned. They concluded that, the temperature between $30^{\circ} \mathrm{C}$ and $60^{\circ} \mathrm{C}$ therefore, influences the biogas generation from lignocellulosic material.

Zhao (2011) evaluates the effect of temperature on biogas production and $C O D_{\text {total }}$ removal from domestic wastewater. There are eight set of temperatures and each is stabilized for seven days. He found that, the temperature rising from $19^{\circ} \mathrm{C}$ to $35^{\circ} \mathrm{C}$ achieves a general benefit result in methane yield rate and $C O D_{\text {total }}$ removal efficiency. He also, added that the best methane yield rate and $C O D_{\text {total }}$ removal rate occurred at temperature of $33.4^{\circ} \mathrm{C}$. Sorathia et al., (2012) reported that, temperature for fermentation will greatly affect biogas production. Depending on prevailing conditions, methane can be produced within a fairly wide range of temperature. The process of anaerobic fermentation and methane forming bacteria works best in the temperature between $29^{\circ} \mathrm{C}$ to $41^{\circ} \mathrm{C}$ or between $49^{\circ} \mathrm{C}$ to $60^{\circ} \mathrm{C}$ and pressure of about 1.1 to 1.2 bars absolute. The temperature between $32^{\circ} \mathrm{C}$ $35^{\circ} \mathrm{C}$ are most efficient for stable and continuous production of methane.

Solar energy collector is a special kind of heat exchanger that transforms solar radiation energy into internal heat energy of the transport medium. Basically, there are two types of flat-plate solar heating collectors; water heating collectors and air heating collectors. The pace of development of air heating collector is slow as compared with water heating collector mainly due to lower thermal efficiency (Ramani et al., 2010). The overall thermal performance of flat-plate solar collectors is mainly influenced by upward heat losses. Appropriate radiative and convective heat transfer coefficients for estimation of upward heat losses have been described (Duffie and Beckman, 2005)

Alkhamis and Kablan (2000) proposed a solar heating system in which solar collector is connected to a heat exchanger and used to heat the water jacket around the bioreactor. A proportional Integral Differential (PID) controller was installed to control the temperature at $40^{\circ} \mathrm{C}$. The overall thermal efficiency of solar collector was found to be around $61 \%$.The controller action was seen to be very effective and a prompt response for a variation of $1^{\circ} \mathrm{K}$ was noticed. Kocar and Eryasar (2007) reviewed the solar heated biogas plants and optimized the insulation thicknesses and solar energy systems for $5 \mathrm{~m}^{3}$ biogas reactor for two different cities and for three different climatic zones in Turkey.

Based on the results, the ratio of annually produced biogas used for reactor heating was calculated for each city, with and without solar heating system. The results indicate that the biogas consumption for reactor heating is decreased by approximately $19 \%$ for average of six cities when solar heating system is used. This means that available biogas potential would be increased. They added that the recent studies in Turkey have shown active heat transfer 
from solar collectors can reduce biogas used for heat requirements to $7 \%$ from $26 \%$ of total gas produced.

A solar heating system was proposed by Dai and Chun (2007) with evacuated tubes with auxiliary electric heater to provide thermal energy for bioreactor. They proposed a system of solar collector combined with heat exchanger. They carried out the experimental work at three different digester temperatures of 15,20 , and $25^{\circ} \mathrm{C}$ and found that the optimum temperature for biogas production was $25^{\circ} \mathrm{C}$. Basrawi et al., (2010) mentioned that, the important energy balance on anaerobic digestion plants is affected by heat demand, whereas the heat is affected by the ambient air temperature. They found that, the heat demand for heating the sludge was temperature-dependent and 26 to 39\% of the total amount of heat demand was heat losses from digester sides. They concluded that the ratio of heat demand to biogas produced had an inverse proportional relation with ambient temperature, whereas ratio of net energy to biogas produced had a proportional relation, and ranges of these values were $0.13-0.44$ and $0.45-0.84$, respectively.

The main objectives of this investigation were to: (1) determine how much energy can be provided by the solar heating system, (2) evaluate the energy balance of $20 \mathrm{~m}^{3}$ biogas digester to determine the total energy required to predict and maintain the digester temperature at the mesophilic temperature, and (3) investigate the effect of the solar heating system on the biogas production.

\section{MATERIALS AND METHODS}

This research work was conducted on the two fixed dome digesters constructed by the "Development of Biogas Production and Utilization Systems Project" which financially supported by the Agricultural Development Program (ADP) and implemented at the Tractors and Machinery Research and Test Station, Alexandria city, Agricultural Engineering Research Institute. The latitude and longitude angles of this station, respectively, are $31.217^{\circ} \mathrm{N}$ and $30.50^{\circ} \mathrm{E}$, and $3.00 \mathrm{~m}$ mean altitude underneath the sea level.

Two fixed dome digesters with the same volume of $20 \mathrm{~m}^{3}$ as showed in Figs. (1 and 2) were utilized to investigate the effect of the digester heating on the biogas productivity. One digester was connected to solar heating system, while the other is unheated. The solar water heating system consists of six individual solar collector panels each having a gross dimensions of 250 $\mathrm{cm}$ long, $90 \mathrm{~cm}$ wide, and $10 \mathrm{~cm}$ thick with net surface area of $2.25 \mathrm{~m}^{2}$, constructed from copper with a selectively absorbing surface coating, and covered with $5 \mathrm{~mm}$ thick thermal clear glass. The operating fluid (mixing of pure water and antifreeze) flowed through parallel waterways built into each panel. The 6 solar collectors are arranged in two banks with three collectors in series array in each bank. Thus all the solution passed through three collectors at a flow rate which was sufficient to give reasonable efficient heat transfer, while still enabling the water to reach $65-75^{\circ} \mathrm{C}$ under ideal conditions.

The operating fluid has pumped to pass through the solar collectors using water pump. After passing through the solar collectors it is stored in a 1000 litres insulated storage tank. The water pump is operated based on a controller unit using differential thermostat. It is switched on when the 
absorber plate temperature inside the solar collectors is higher than that in the storage tank and switched off when the water temperature inside the storage tank is higher than that the absorber plate. The storage tank is connected to the solar collectors by two junctions of insulated hot galvanized pipes $25.4 \mathrm{~mm}$ (1.0 inch) diameter. One junction is between the bottom of the storage tank and the bottom of the first solar panel in the first bank (water inlet). The other junction is between the top of the storage tank and the last panel in the second bank (water outlet). An auxiliary electric heater (6 kWh) is situated inside the storage tank and used to heat the water when the solar radiation was insufficient to raise the tank temperature into $85^{\circ} \mathrm{C}$.

The storage tank is connected to a heat exchanger which vertically located inside the biogas digester by two junctions in order to provide heat energy in the digester. A $25.4 \mathrm{~mm}$ stainless steel pipe coil is used as a heat exchanger having a diameter of $2.7 \mathrm{~m}$ and with total length of $126 \mathrm{~m}$. Hot water (heated by solar energy) at the end of daylight is circulated using water pump (1 hp and $4 \mathrm{~m}^{3} / \mathrm{h}$ volumetric flow rate) for heating the sludge in the biogas digester and returned to the storage tank as low-temperature water (lower than the heat energy inside the storage tank). The digester was also, equipped with type $\mathrm{K}$ temperature sensor, which connected with digital thermostat to adjust the digester temperature at $37 \pm 2^{\circ} \mathrm{C}$ (Gao et al., 2011). The sludge temperature inside the biogas digester is monitored using an ON-OFF controller (differential thermostat) to initiate heating at $35^{\circ} \mathrm{C}$ and interrupt it at $37^{\circ} \mathrm{C}$.

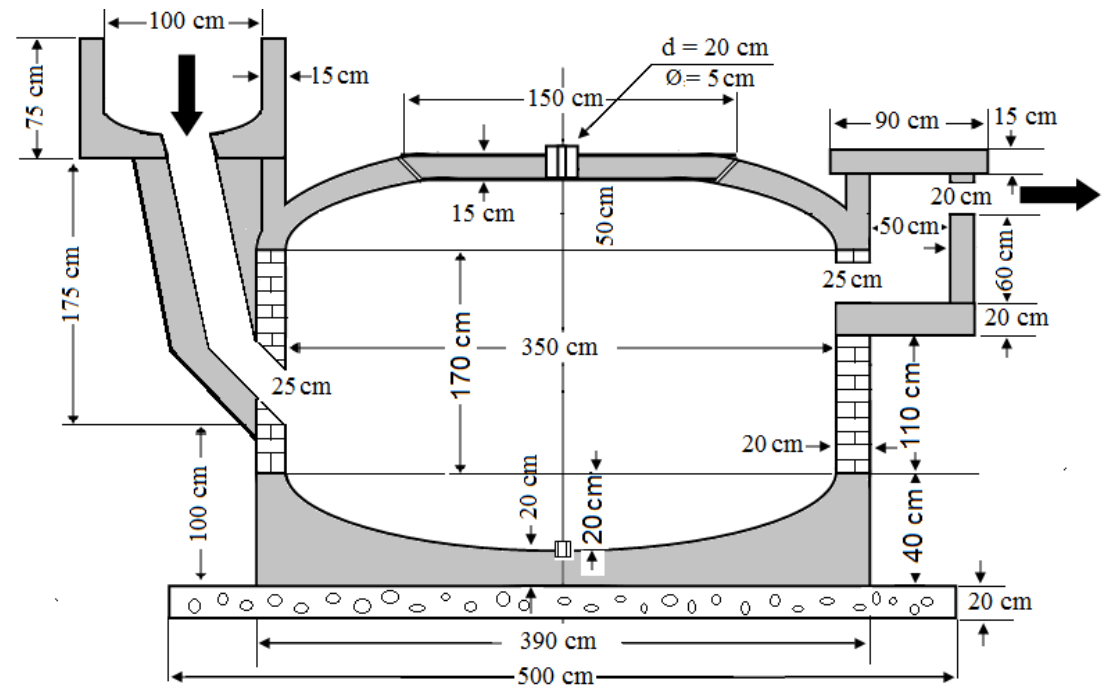

Fig. (1): The digester specification. 


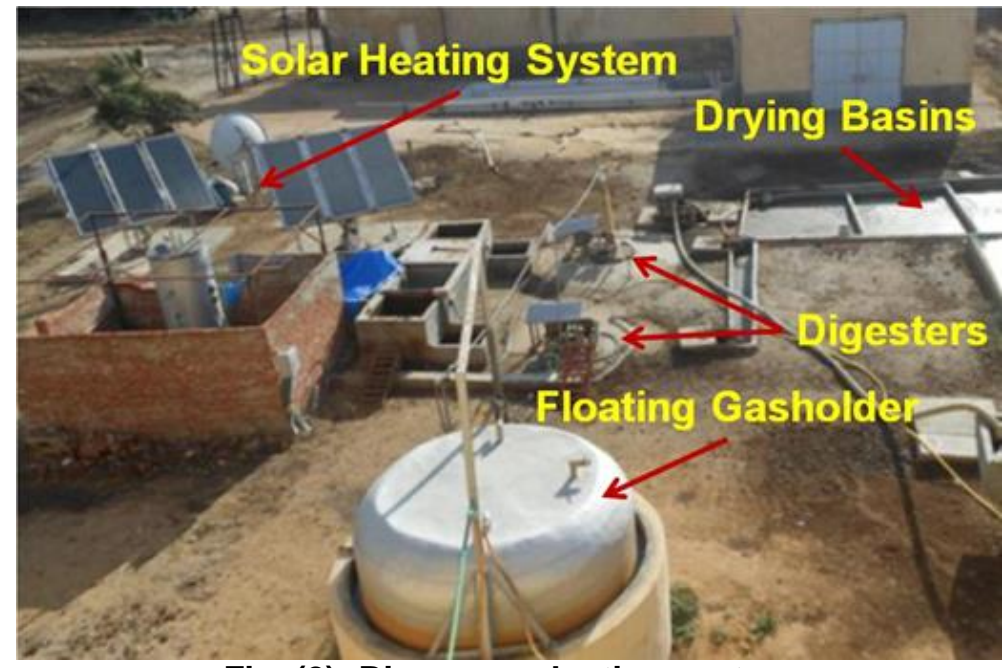

Fig. (2): Biogas production system

The main substrate utilized in this research work was dairy cow dung which obtained from Farma Key Farm for Animal Production, Faculty of Agriculture- Alexandria University.

\section{Laboratory analyses}

The chemical analysis of dairy cow dung was carried out to determine its properties. The following parameters were determined using standard laboratory methods (APHA, 1998): total solids (TS), total volatile solids (VS), organic carbon (OC), and Total Kjeldahl nitrogen (TKN). The temperatures of slurry in the two digesters, water inlet and outlet from storage tank to the solar system, hot water inlet and outlet from storage tank to the heated digester, soil and ambient were recorded with thermocouples type $\mathrm{K}$ connected to data logger type (Datataker DT85, USA). The solar radiation incident was measured by Pyranometer type Kipp and Zohne solarimeter (Pyranometer, Kipp and Zohne, Holand) and recorded by the same Datataker DT85.The biogas production was collected in $20 \mathrm{~m}^{3}$ floating gas holder and it was measured daily using the scaling ruler fixed on the gasholder side.

\section{Model development}

\section{1- Thermal analysis of solar system.}

The solar collector tilt angle was adjusted at an optimum tilt angle $(\beta)$ at noon for the average day each month using the following equation (Duffie and Beckman, 2005) and listed in Table (1):

$\beta=$ Latitude angle - declination angle

\section{(1)}

Table (1): Monthly optimum tilt angle of solar panels for Alexandria city, (Latitude angle $31.217^{\circ} \mathrm{N}$ ).

\begin{tabular}{|c|c|c|c|c|c|c|c|c|c|c|c|}
\hline Jan & Feb & Mar & Apr & May & Jun & Jul & Aug & Sep & Oct & Nov & Dec \\
\hline 52 & 44 & 33 & 21 & 12 & 8 & 10 & 18 & 29 & 41 & 50 & 54 \\
\hline
\end{tabular}
equation:

The solar declination angle $(\delta)$ can be calculated using the following

$$
\delta=23.45 \sin [0.9863(n+284)]
$$


Where, $\mathrm{n}$, is the number of the day from the first of January.

The solar energy available can be derived in terms of solar radiation flux incident on the solar collector surface, and the surface area of solar collector. Thus, the solar energy available $(\mathrm{Q})$ can be computed from the following equation, (Duffie and Beckman, 2005):

$$
\mathbf{Q}=1 \mathbf{A}_{\mathrm{c}}, \quad \text { Watt }
$$

Where, I and $A_{C}$, respectively, are the solar radiation flux incident on the collectors surface in $\mathrm{Wm}^{-2}$ and the surface area of the solar collector in $\mathrm{m}^{2}$. However, a part of this radiation is reflected back to the sky, another component is absorbed by the glazing and the rest is transmitted through the glazing and reaches the absorber plate as shortwave radiation. Therefore, the actual solar energy absorbed $\left(Q_{a}\right)$ by the absorber plate is the product of the solar energy available $(Q)$ and the optical efficiency $(\tau \alpha)$.
$Q_{a}$ $=\mathbf{Q}(\mathbf{T \alpha})$,
Watt

Where, $\alpha$, is the effective absorptance of the absorber plate, (decimal) and, $\mathrm{T}$, is the effective transmittance of the solar collector covering system (decimal). They can be computed from the following equations:

$$
\begin{array}{lll}
\alpha & =0.96-0.00476 \exp [0.0940(\theta-35)] \\
\mathrm{T} & =0.95-0.00437 \exp [0.0936(\theta-30)]
\end{array}
$$

The solar incident angle $(\theta)$ can be found from the following formula for solar collector orientated east-west and facing south:

$$
\theta=\operatorname{arcos}\left[\cos \psi \cos \gamma_{\mathrm{s}} \sin \beta+\sin \psi \cos \beta\right]
$$

The solar azimuth angle $\left(\mathrm{Y}_{\mathrm{s}}\right)$ can be determined by the following equation:

$$
\mathbf{Y}_{\mathrm{s}}=\operatorname{arcos}\left[\frac{\cos \delta \sin \omega}{\cos \psi}\right], \quad \text { degree }
$$

Where, $\omega$, and $\psi$, respectively, are the solar hour angle and solar altitude angle. They can be found from the following equations:

$$
\begin{array}{lll}
\omega & =15(\text { LAT }-12), & \text { degree }
\end{array}
$$

As the solar collector absorbs heat, its temperature is being higher than that the surrounding and heat energy is therefore lost to the atmosphere by convection and radiation. The rate of heat energy loss $\left(Q_{L}\right)$ depends on the solar collector overall heat transfer coefficient $\left(U_{0}\right)$ and the temperature difference between the mean absorber plate and the ambient air. It can be computed by the following formula:

$$
Q_{L} \quad=U_{0} A_{C}\left(T_{p}-T_{a}\right) \text {, Watt }
$$

The maximum possible useful energy gain (heat transfer) in a solar collectors occurs when the whole collector is at the inlet fluid (water) temperature, heat losses to the surroundings are then at minimum. The useful heat energy gain can be computed by the following equation:

$$
Q_{\text {useful }}=Q_{a}-Q_{L}=Q(T \alpha)-\text { Uo } A_{C}\left(T_{p}-T_{a}\right) \text {, Watt (12) }
$$

The extraction rate of heat energy (useful heat gain) from the solar collector may be measured by means of the amount of heat energy acquired by the water passed through it, as:

$$
\mathbf{Q}_{\text {useful }}=\mathrm{m} \mathrm{C}_{\mathrm{p}}\left(\mathrm{T}_{\mathrm{o}}-\mathrm{T}_{\mathrm{i}}\right), \quad \text { Watt }
$$


Solar collector overall thermal efficiency depends strongly upon the useful heat gain and the energy collected by the collector. The solar collector overall thermal efficiency can be found from the following equation:

$$
\eta_{\mathrm{o}}=\frac{Q_{\text {useful }}}{Q} \times 100=\frac{m C_{p}\left(T_{o}-T_{i}\right)}{I A_{C}} \times 100, \%
$$

\section{2- Thermal analysis of heated biogas digester:}

The transient energy balance of the system as shown in Fig (3) can be achieved by the following equations:

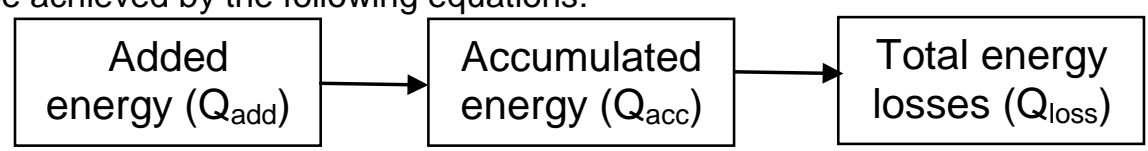

Fig. (3): The system energy balance

$$
Q_{\text {acc }}=Q_{\text {add }}-Q_{\text {loss }}
$$

Where, $Q_{a c c}$, is the accumulated heat energy in the digester in $\mathrm{kWh}$, $\mathrm{Q}_{\mathrm{add}}$, is the added heat energy in $\mathrm{kWh}$, and, $\mathrm{Q}_{\text {loss }}$, is the total heat energy losses in $\mathrm{kWh}$.

The accumulated heat in the manure inside the digester can be computed from the following equation:

$$
\mathbf{Q}_{\mathrm{acc}}=\mathbf{M} \mathbf{C p} \frac{d T}{d t}, \mathbf{k W h}
$$

Where, $M$, is the mass of manure in the digester in $\mathrm{kg}, \mathrm{C}_{\mathrm{p}}$, is the specific heat of the manure $\left(\mathrm{kJ} \mathrm{kg}^{-1}{ }^{\circ} \mathrm{C}^{-1}\right), \mathrm{dT} / \mathrm{dt}$, is the difference in temperature of the manure through a certain time, $\mathrm{dt}$, in ${ }^{\circ} \mathrm{C} \mathrm{s}^{-1}$

The heat added from the storage tank can be calculated by the following equation:

$$
Q_{\text {add }}=\mathrm{m} \mathrm{C}_{\mathrm{p}}\left(\mathrm{T}_{\text {in }}-\mathrm{T}_{\text {out }}\right), \quad \mathrm{kWh}
$$

Where, $\mathrm{m}$, is the water mass flow rate in $\mathrm{kg} \mathrm{s}^{-1}, \mathrm{C}_{\mathrm{p}}$, is the specific heat of water in $\mathrm{kJ} \mathrm{kg}^{-1}{ }^{\circ} \mathrm{C}^{-1}$, and, $\mathrm{T}_{\text {in }}$ and $\mathrm{T}_{\text {out }}$, are the inlet and outlet water temperatures, respectively, in ${ }^{\circ} \mathrm{C}$.

The total heat losses from the digester whole body can be computed from the summation of each part heat loss as follows:

$$
Q_{\text {loss }}=Q_{\text {wall }}+Q_{\text {bottom }}+Q_{\text {top }}+Q_{\text {batch }}, \mathbf{k W h}
$$

Where, $Q_{\text {wall }}$, is the total surface area of digester (cylindrical in shape) in $\mathrm{m}^{2}$, it can be calculated as follows:

$$
\mathbf{Q}_{\text {wall }}=\frac{2 \pi k L\left(T_{m}-T_{s}\right)}{\ln \left(r_{o} / r_{i}\right)}, \quad \mathbf{k W h}
$$

Where, $\mathrm{k}$, is the thermal conductivity of wall material in $\mathrm{W} \mathrm{m}^{-1}{ }^{\circ} \mathrm{C}^{-1}$, $\mathrm{L}$, is the total length of heat exchanger in $\mathrm{m}, \mathrm{T}_{\mathrm{m}}$, is the temperature of slurry in ${ }^{\circ} \mathrm{C}$, Ts, is the soil temperature in ${ }^{\circ} \mathrm{C}$, and, $r_{0}$ and $r_{i}$, are the outer and inner radius of the heat exchanger, $\mathrm{m}$

The heat losses from the top of the digester can be computed using the following equation:

$$
\mathbf{Q}_{\mathrm{top}}=\frac{k A_{t}\left(T_{m}-T_{a}\right)}{d x_{t}}
$$


Where, $A_{t}$, is the wall surface area in $\mathrm{m}^{2}$, and, $\mathrm{dx}_{t}$, is the thickness of top surface in $\mathrm{m}$

The heat losses from the bottom of digester can be computed as follows:

$$
\mathbf{Q}_{\text {bottom }}=\frac{k A_{b}\left(T_{m}-T_{s}\right)}{d x_{b}}
$$
bottom, $\mathrm{m}$

Where, $A_{b}$, is the bottom surface area in $m^{2}, d x_{b}$, is the thickness of

The heat losses due to interring a mass of new batch of manure $\left(\mathrm{m}_{\mathrm{b}}\right.$, in $\mathrm{kg}$ ) each day, to raise the batch temperature into the digester temperature can be computed from the following equation:

$$
Q_{\text {batch }}=m_{b} C_{p}\left(T_{m}-T_{a}\right)
$$

A fortran computer program was developed using the above mathematical equations. The FORTRAN program is consisted of one main program and two subroutines. The first subroutine handles the solar energy data to compute the incident solar radiation, the available solar radiation on the absorber plate, the solar collector heat losses, and the heat gain by the solar system. The second subroutine dials with the digester energy balance and returns the total heat losses from the digester sides, the heat energy added, and the accumulated heat within the digester manure. Then the main program computes the shared heat energy added by the solar system and the electrical heater inside the storage tank, finely it can predict the digester temperature.

The biogas production from the two digesters were measured daily using a scaling ruler placed on the gasholder, whereas, the methane content, carbon hydroxide and hydrogen sulfate were measured by GA 5000 gas analyzer. In addition, the periodically gas samples were analyzed at Chemical Laboratory of Petroleum Research Institute to determine the gross and net energy content of biogas and its density. The daily biogas production is mainly recorded at atmospheric temperature and pressure $\left(0^{\circ} \mathrm{C}\right.$ and 1.013 bar) as mentioned by Gosch et al., (1983) using the following equation:

$$
\mathrm{V}_{\mathrm{tr}}=\frac{V_{f}\left[273.15\left(P_{1}-P_{2}-P_{3}\right)\right]}{[273.15+T] \times 1013} \quad \mathrm{~m}^{3},
$$

Where, $V_{t r}$, is the volume of gas under standard condition, $V_{f}$, is the volume of wet gas at pressure $P$ and temperature $T, P_{1}$, is the atmospheric pressure at temperature $T, P_{2}$, is the Pressure of wet gas at temperature $T, P_{3}$, is the saturation steam pressure of water at temperature $\mathrm{T}$, and, 1013, is the absolute pressure in milli-bar. The average temperature inside the two digesters through the anaerobic digestion period was about 27 and $37^{\circ} \mathrm{C}$ for unheated and heated digesters, respectively. While, the gas pressure $\left(P_{2}\right)$ ranged from 18.95 to 36.83 milli-bar with an average of 29.33 milli-bar. In addition, the atmospheric pressure $\left(P_{1}\right)$ ranged from 1011 to 1018 milli-bar with the range of 1014 milli-bar at $20^{\circ} \mathrm{C}$. All measurements of biogas rate and energy were recorded daily and the average of every week was evaluated and discussed in the results. 


\section{RESULTS AND DISCUSSION}

The output results of the first subroutine of the computer program are illustrated in Figs (4a and $4 b$ ). The figures pointed out the influence of the solar energy incident, transmitted, gained and lost by the solar system for the four successive days in November and December months of 2014. The actual solar radiation recorded on the tilted surface of solar collectors was always higher than that on the horizontal surface. Under clear sky conditions, the solar energy available $(Q)$, absorbed solar energy $\left(Q_{a}\right)$, useful heat gain to storage $\left(Q_{u}\right)$, overall thermal efficiency $\left(\eta_{0}\right)$, and solar energy stored in the storage tank increased gradually with solar time from sunrise to sunset till they attained the maximum values at noon. They then declined until reached the minimum values prior to sunset. The solar radiation flux incident (I) on the horizontal and tilted surfaces during the heating period was varied from hour to hour, day to another, and during the heating period as shown in Figs ( $4 a$ and $4 b$ ). These variations occurred due to the sky conditions, solar altitude angle, and solar incident angle.

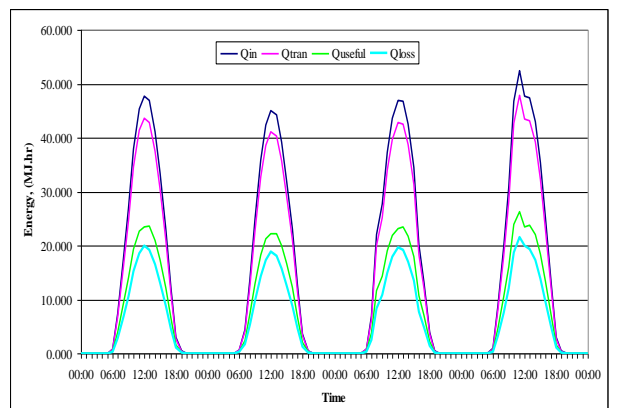

a- November

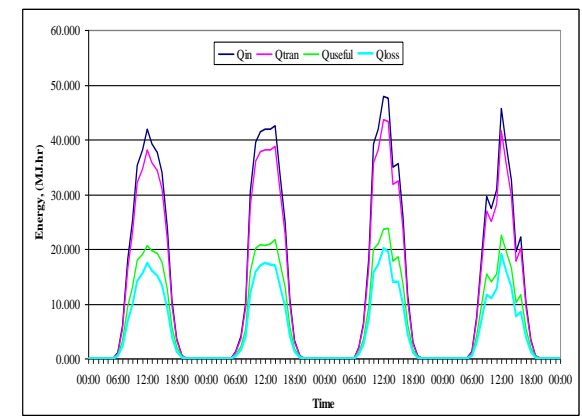

b- December

Fig. (4): Solar energy flux incident, transmitted, gained and lost by the solar system for the four successive days during November and December 2014.

For the duration of November, the daily averages solar energy available, absorbed solar energy, useful heat gain, and heat losses from the solar collectors, respectively, were $100.425,91.539,51.383$, and 40.156 $\mathrm{kWh}$, while, during December month they were 91.253, 83.178, 43.889 and $39.289 \mathrm{kWh}$, respectively. Whereas the useful heat gain to storage was represented 56.13 and $52.77 \%$ of the absorbed solar radiation at the same months, respectively. On the other hand, the average heat loss percentage was 43.87 and $47.23 \%$ in the same months, respectively. The previous figures also revealed that, the heat losses from the solar collectors during December month were higher than that in November. This variation may be attributed to decrease the ambient air temperature surrounding the solar system resulting in increasing the heat losses.

The temperatures of the unheated digester $\left(T_{d 1}\right)$, heated digester $\left(T_{d 2}\right)$, storage tank temperature $\left(T_{k 1}\right)$, water return to storage tank $\left(T_{k 2}\right)$, ambient $\left(T_{a}\right)$, bottom soil $\left(T_{s 1}\right)$ and side wall of the heated digester $\left(T_{s 2}\right)$ for November and December months are shown in Figs.(5a and $5 b)$. These data 
were fed to the second subroutine as input data. The obtained results showed that, the both digesters temperature was affected by the soil temperature, i.e. increasing the soil temperature increases the digester temperature and vice versa. This is due to difficult of isolating the digester wall due to the high ground water level. They also, showed that, the soil temperature was daily decreased through the period from 9 am to $4 \mathrm{pm}$ and accordingly the digesters temperatures. While, outside this period, the soil temperature was increased resulting in increasing the digester temperature and consequently providing the heat energy demand.

The daily averages heat energy added by the heat exchanger $\left(Q_{a d d}\right)$, which is the sum of the heat gained by the solar collectors $\left(Q_{\text {useful }}\right)$, and the heat energy added by the auxiliary heater $\left(Q_{\text {heater }}\right)$, the digester heat losses $\left(Q_{\text {Dloss }}\right)$, and the net heat energy $\left(Q_{\text {net }}\right)$ are illustrated in Fig. (6). The obtained results showed that, the daily average useful heat energy gained by the solar heating system $\left(Q_{\text {useful }}\right)$, the auxiliary heat energy by the electrical heater $\left(Q_{\text {heater }}\right)$, the digester heat losses $\left(Q_{\text {Dloss }}\right)$ and the net heat remained in the digester during November month, respectively, were 51.383, 27.306, 69.822 and $8.867 \mathrm{kWh}$, while during December they were 43.888, 41.156, 83.653, and $1.391 \mathrm{kWh}$, respectively. These data clarified that, the solar heating system provided 65.30 and $51.61 \%$, of the daily total heat energy required during November and December months, respectively. It also, clears that the daily average heat losses by the digester to the soil during December month were higher than that in November due to decreasing the soil temperature.
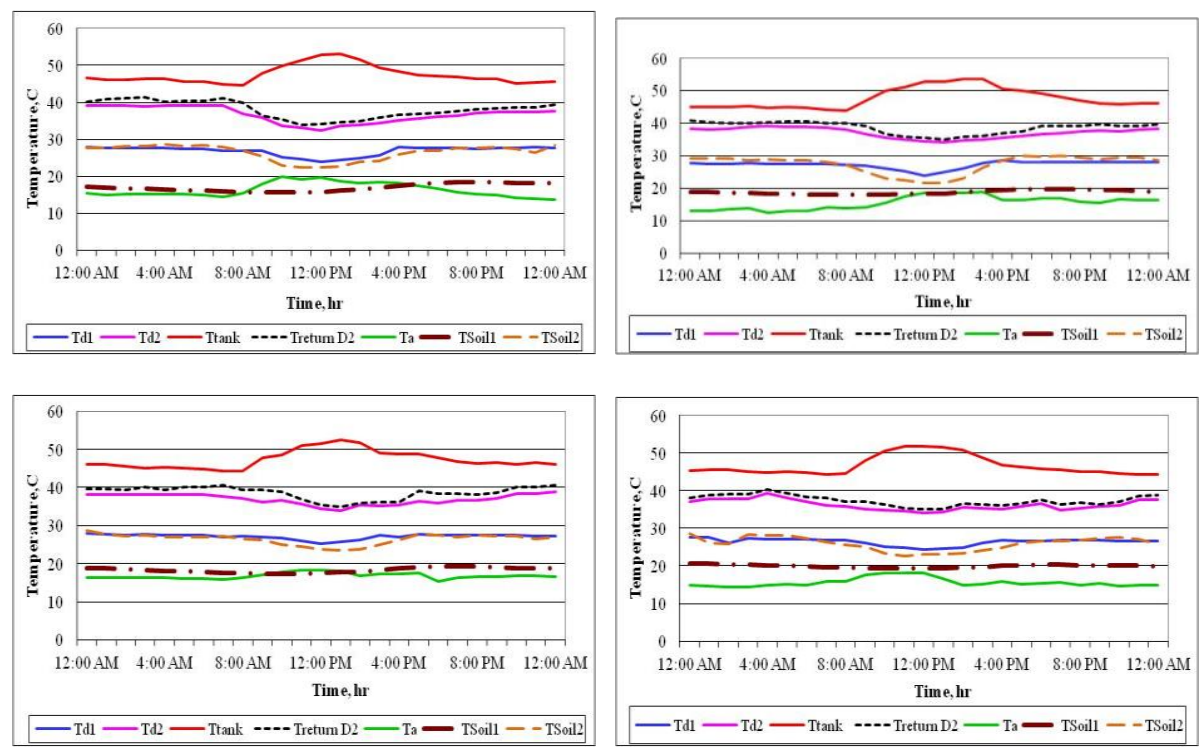

Fig. (5a): The temperatures of the unheated digester $\left(T_{d 1}\right)$, heated digester $\left(T_{d 2}\right)$, storage tank $\left(T_{k 1}\right)$, the water return to storage tank $\left(T_{k 2}\right)$, ambient air, bottom soil $\left(T_{s 1}\right)$ and side wall of the heated digester $\left(T_{s 2}\right)$ for November month. 

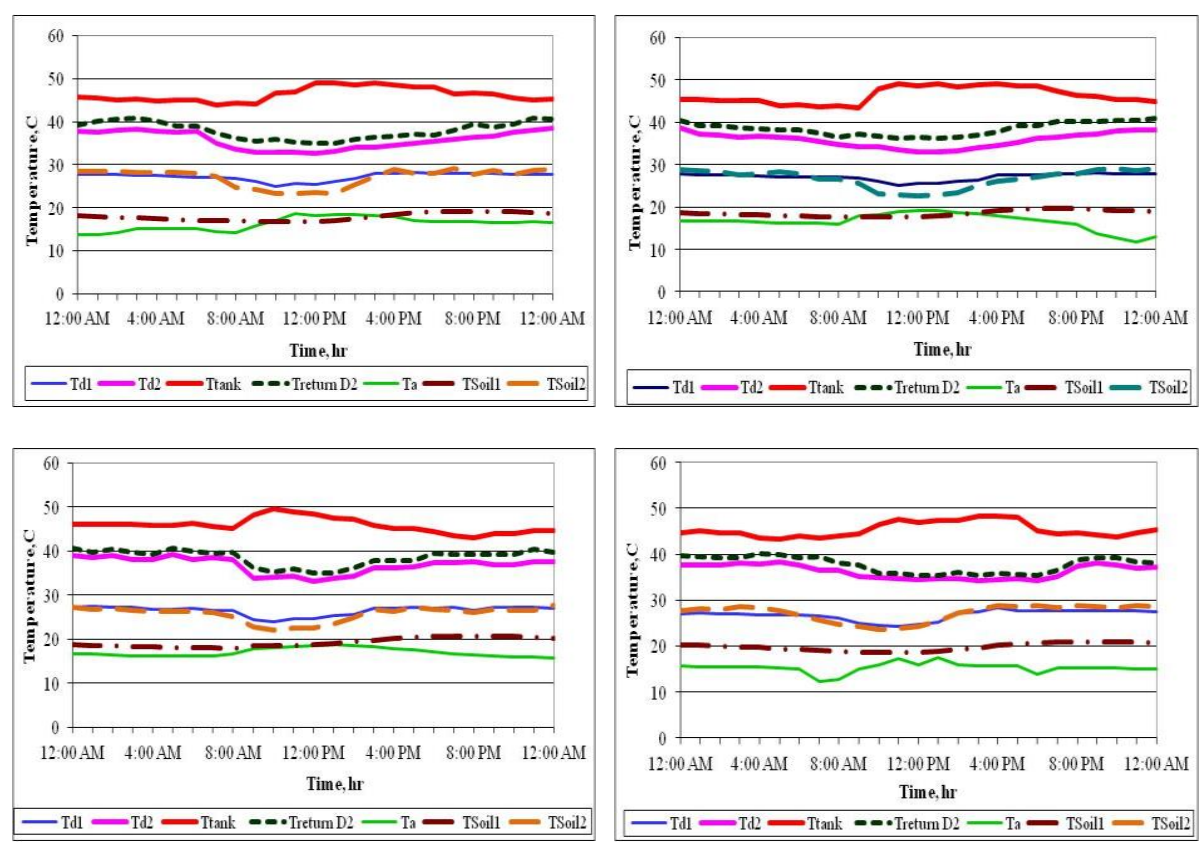

Fig. (5b): The temperatures of the unheated digester $\left(T_{d 1}\right)$, heated digester $\left(T_{d 2}\right)$, storage tank $\left(T_{k 1}\right)$, the water return to storage tank $\left(T_{k 2}\right)$, ambient air, bottom soil $\left(T_{s 1}\right)$ and side wall of the heated digester $\left(T_{s 2}\right)$ for December month.

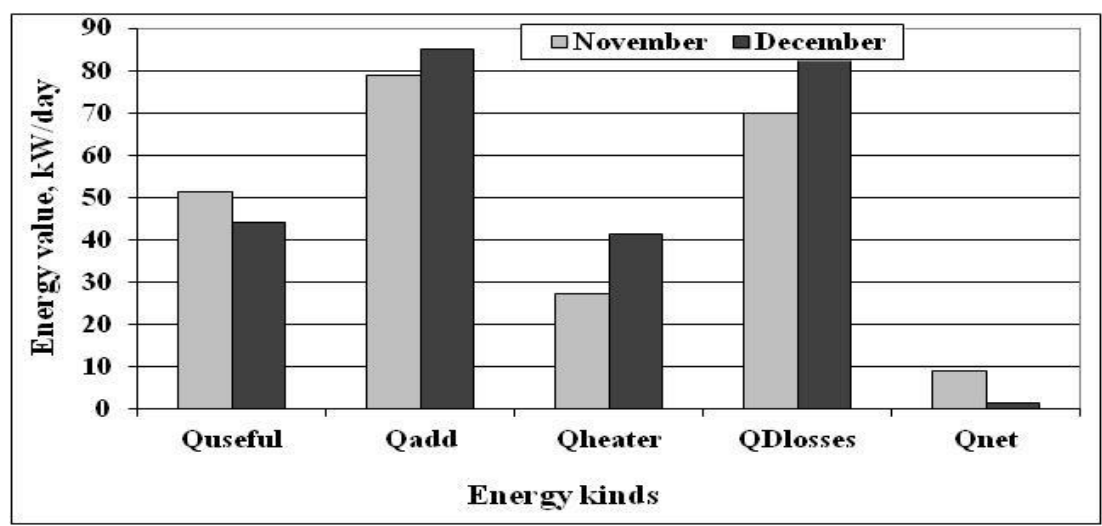

Fig. (6): The daily averages heat energy added by the heat exchanger $\left(Q_{\text {add }}\right)$, heat energy gained by the solar collectors, $\left(Q_{\text {useful }}\right)$, heat energy added by the electrical heater $\left(Q_{\text {neater }}\right)$ and the net heat energy $\left(Q_{\text {net }}\right)$.

The predicted and measured digester temperatures for the two months (November and December) are plotted in Fig. (7). This data revealed that, the predicted digester temperature was under estimation through the night time and over estimation through the day time. The error root mean square was 1.66 and $1.83^{\circ} \mathrm{C}$ in the two representative days for November 
and December months, respectively. These lower values indicated that the program has an excellent degree of prediction.

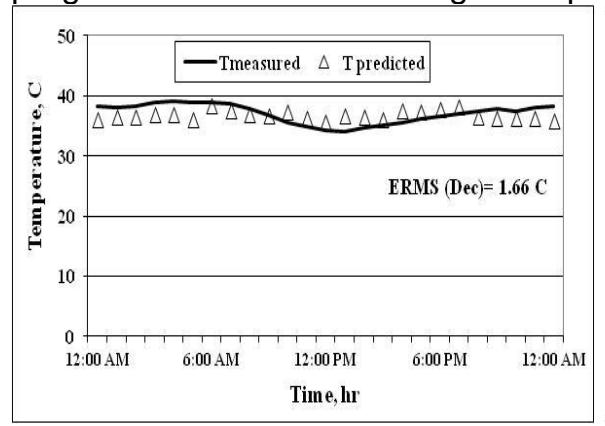

a- November

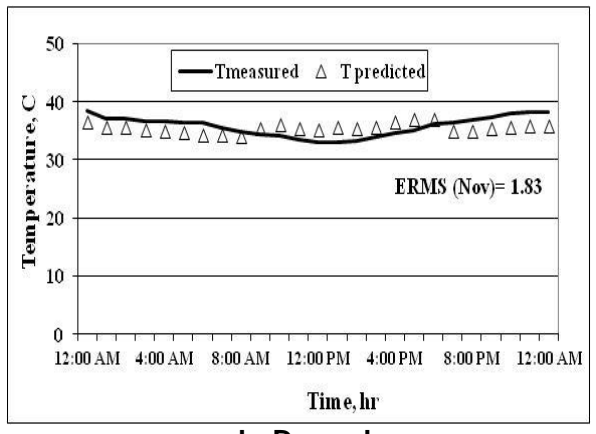

b- December

Fig. (7): The predicted and measured digester temperatures for November and December months.

- $\quad$ Effect of heating process on biogas production

The solar heating system was used to heat the biogas digester to provide and maintain the digestion temperature at the desirable level of micro-organisms. The digestion temperature inside the digester was adjusted at $37 \pm 2^{\circ} \mathrm{C}$. The effect of digester heating process was evaluated through six weeks and the results are illustrated in Figs (8 to11). The obtained results showed that, the heated digester gave a higher biogas production rate as compared with the digester that operated (without heating) at the ambient temperature (21 \pm 2 ) as revealed in Fig.(8). The biogas production rate of the heated digester ranged from 0.510 to $0.532 \mathrm{~m}^{3} / \mathrm{m}^{3}$ per day with an average of $0.524 \mathrm{~m}^{3} / \mathrm{m}^{3}$ per day while, it ranged from 0.283 to $0.317 \mathrm{~m}^{3} / \mathrm{m}^{3}$ per day with an average of $0.306 \mathrm{~m}^{3} / \mathrm{m}^{3}$ per day for the unheated digester. The increasing ratio was $71.4 \%$. These obtained results were higher than that obtained by Rennuit and Sommer (2013), when they reported that, heat the digester to $35^{\circ} \mathrm{C}$ improve the biogas production by $50 \%$ as compared with the digester operated at the ambient temperature. Moreover, the average biogas productivity per $\mathrm{kg}$ of total solids added was 0.133 and $0.077 \mathrm{~m}^{3} / \mathrm{kg}$ of TS added for heated and unheated digesters, respectively.

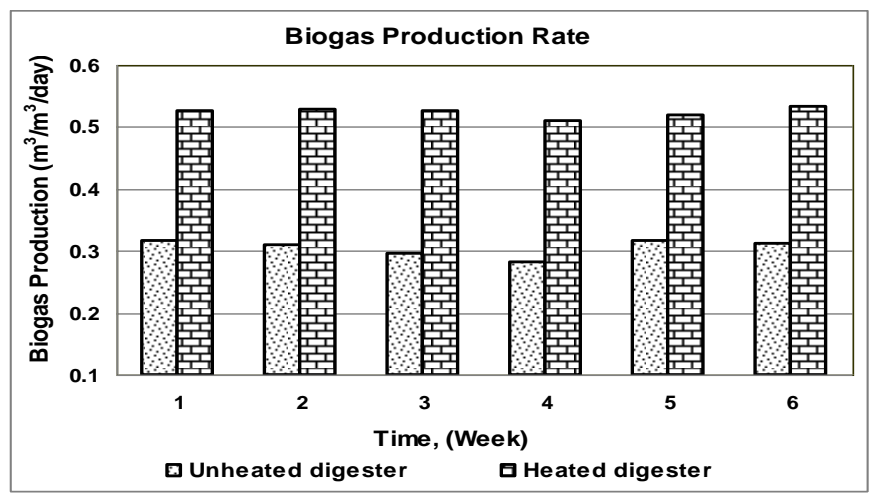

Fig. (8): Biogas production rate from heated and unheated biogas digesters 
Meanwhile, the average biogas productivity per kg volatile solids (VS) destroyed is plotted in Fig. (9). The obtained results indicated that, the heated digester gave the higher productivity of biogas as compared with the unheated digester. This variation may be due to increase the activity of methanogensess at high and stability of digester temperature. The average biogas productivity was, $0.722 \mathrm{~m}^{3} / \mathrm{kg}$ of VS destroyed for heated digester as compared with $0.456 \mathrm{~m}^{3} / \mathrm{kg}$ of VS destroyed with unheated digester. These results are in agreement with the data published by Bolzonella et al. (2005), when they used the mesophilic $\left(35-37^{\circ} \mathrm{C}\right)$ anaerobic digestion process and concluded that, the specific gas production per kilogram of volatile solids destroyed was in the range $0.5-0.9 \mathrm{~m}^{3} / \mathrm{kg}$ of VS destroyed. In addition, the average methane percentage in biogas was 63.46 and $62.39 \%$ for the heated and unheated digesters, respectively. These results revealed that increasing the digester temperature dose not have a significant effect on methane content in the produced biogas.

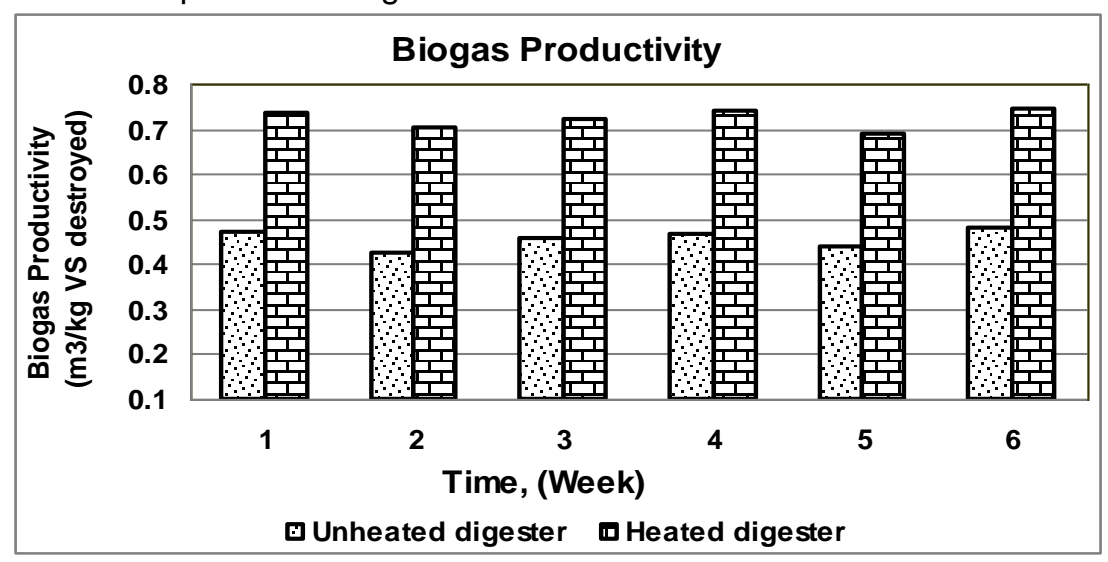

Fig. (9): Biogas productivity for the heated and unheated biogas digesters

The heat energy balance of heated digester is illustrated in Fig. (10). The obtained results revealed that, the heat energy production rate ranged from 3.292 to $3.431 \mathrm{kWh} / \mathrm{m}^{3}$ with an average of $3.361 \mathrm{kWh} / \mathrm{m}^{3}$ per day for the heated digester. While, the average heat energy consumed for heating the biogas digester was $0.970 \mathrm{kWh} / \mathrm{m}^{3}$. This value included the power consumed by the two water pumps and auxiliary heater. The net heat energy gained from the two digesters is plotted in Fig. (11). It revealed that, the heated digester was gave higher net heat energy as compared with unheated digester. The daily averages heat energy production and net heat energy from the unheated digester, respectively, were 1.927 and $2.392 \mathrm{kWh} / \mathrm{m}^{3}$. Consequently, the heated digester increased the net heat energy gained by $24.1 \%$. This ratio of net energy was lower than that obtained by Basrawi et al. (2010) when they concluded that, the net heat energy gained was $45 \%$. This variation may be due to rise the water-table level surrounding the digesters and difficult insulation of the digester which resulting in increasing the heat losses. 


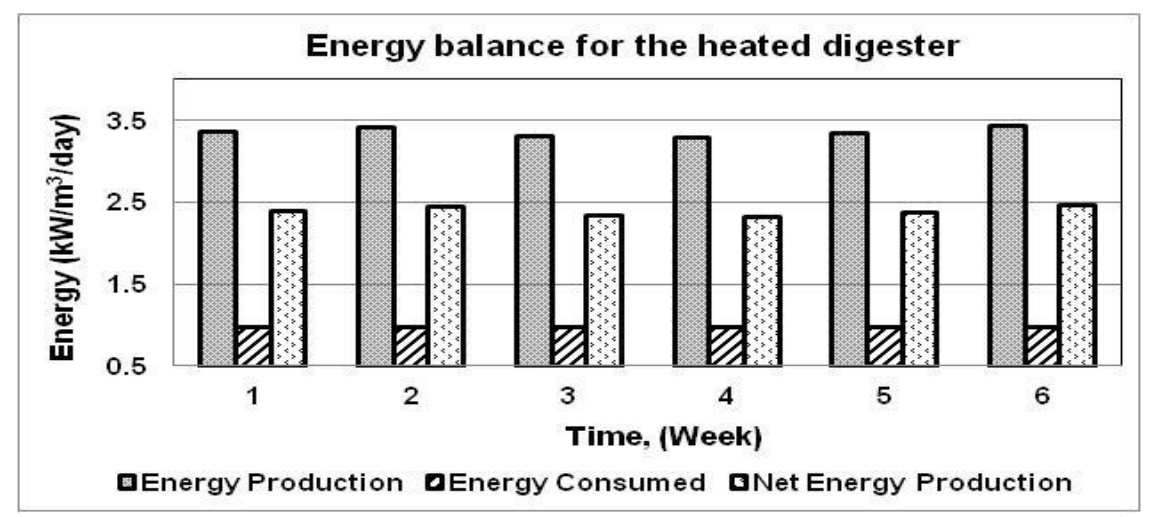

Fig. (10): Energy production, consumed and net heat energy gained from the heated digester.

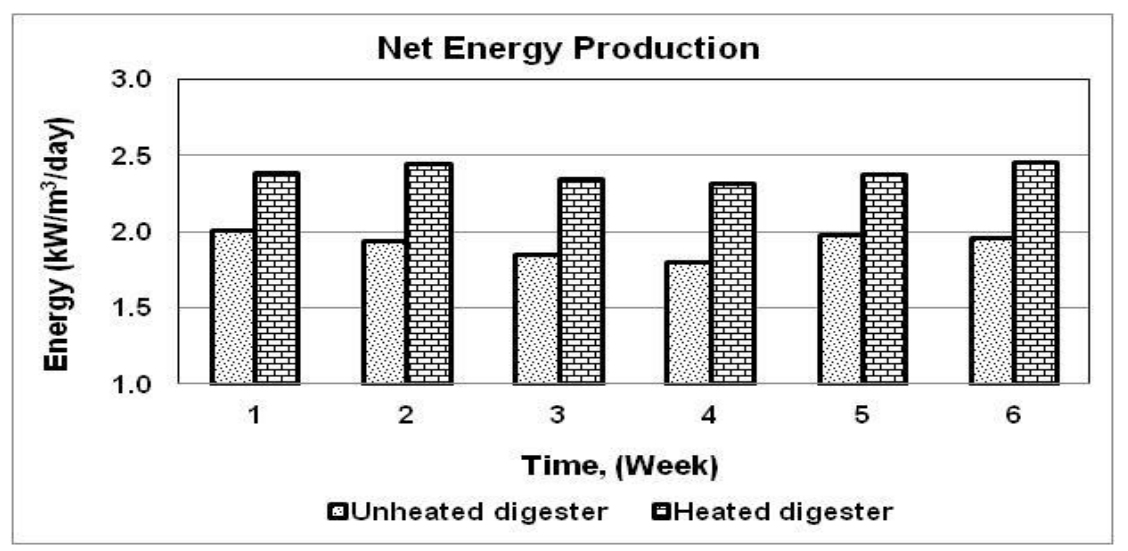

Fig. (11): The net energy gained from the heated and unheated digesters.

\section{CONCLUSION}

In this study the heat balance of biogas digester, the solar collector's performance, and gross and net energy production from biogas digesters were investigated and the following conclusion can be drawn as:

1. The daily average percentage useful heat gained for November and December months was 56.13 and $52.77 \%$ of the solar energy absorbed, respectively. While, the daily average percentage heat loss was 43.90 and $47.23 \%$ for the same months, respectively.

2. The daily average heat energy added to the digester $\left(Q_{a d d}\right)$ and the digester heat losses $\left(Q_{\text {Dlosses }}\right)$ for November month were 78.689, and $69.822 \mathrm{kWh}$, while they were 85.044 , and $83.653 \mathrm{kWh}$ for December, respectively.

3. The solar heating system during November and December months was provided 65.30 and $51.61 \%$, respectively.

4. The average increasing ratio in gross and net biogas energy as a result of heating process was $71.4 \%$ and $24.1 \%$, respectively. 


\section{RECOMMENDATION}

It is clear that, the high level of the water-table make it difficult to insulating the digester resulting in increasing the energy losses and the total burden of heating for providing and maintaining the digester at the desired temperature. So, it is recommended to build the digester above the ground at location with high water-table level, to make it possible to thermally insulate.

\section{REFERENCES}

Alkhamis, T.M.; and M. M. Kablan (2000) "Heating of biogas reactor using a solar energy system with temperature control unit" Solar Energy, 69(3): 239-247.

Alvarez, R.; and G. Lide'n (2008) "The effect of temperature variation obiomethanation at high altitude" Bioresearch Technology, 99: 72787284

APHA, (1998) "Standard Methods for the Examination of Water and Wastewater" 20 th ed. APHA, AWWA, ASSA WPCF, Washington, DC.

Basrawi, F.,; T. Yamada; and K. Nakanishi (2010) "Effect of ambient temperature on the energy balance of anaerobic digestion plants" $\mathrm{J}$. of Envero. and Eng., 5(3): 526-438.

Bolzonella, D.; P. Pavan; P. Battistonic; and F. Cecchi (2005) "Mesophilic anaerobic digestion of waste activated sludge: influence of the solid retention time in the wastewater treatment process" Process Biochemistry, 40:1453-1460.

Choorit, W.; and P. Wisarnwan (2007) "Effect of temperature on the anaerobic digestion of palm oil mill effluent" Electronic Journal of Biotechnology ISSN: 0717-3458, 10(3)

Dai, R.; and C. Chun (2007) "Application of solar heating system in biogas production" Proceedings of ISES Solar World Conference

Duffie, J. A.; and W.A. Beckman (2005) "Solar Engineering of Thermal Processes" $3^{\text {rd }}$ edition, John Wiley and Sons, New York, USA

Gao, W. J.; K.T. Leung; W. S. Qin; and B.Q. Liao (2011) "Effects of temperature and temperature shock on the performance and microbial community structure of a submerged anaerobic membrane bioreactor" Bio-resource Technology, 102: 8733-8740

Gosch, A.; M. Hildegart; W. Ursula; and J. Walter (1983) "The anaerobic treatment of poultry manure" Animal Res. and Dev., 17: 62-73.

Graaff, M. S.; H. Temmink; G. Zeeman; J. N. Cees; and M. Buisman (2010) "Anaerobic treatment of concentrated black water in a UASB reactor at a short HRT" Water, 2:101-119.

Kim, J. K.; B. R. Oh; Y. N. Chun; and S. W. Kim (2006) "Effects of temperature and hydraulic retention time on anaerobic digestion of food waste" J. of Bioscience and Bioengineering, 102(4): 328-332.

Kocar, G.; and A. Eryasar (2007) "An application of solar energy storage in the gas: Solar heated biogas plants" Energy Sources, Part A, 29:1513 1520. 
Kymäläinen, M.; K. Lähde; M. Arnold; J. M. Kurola; M. Romantschuk; and H. Kautola (2012) "Bio-gasification of bio-waste and sewage sludgeMeasurement of biogas quality" J. of Environmental Management, 95: $122-127$

Manik D.; P. Vikram; and M. Datta (1994) "Effect of temperature and retention time on bio-methanation of cheese whey poultry wastecattle dung" J. of Environmental Pollution, 83: 311-318.

Ramani, B. M.; Gupta, A.; and Kumar, R. (2010) "Performance of a double pass solar collector" Solar Energy, 84:1929-1937

Rennuit, C.; and S. G. Sommer (2013) "Decision Support for the Construction of Farm-Scale Biogas Digesters in Developing Countries with Cold Seasons" Energies, 6: 5314-5332.

Song, Y. C., S. J. Kwon, and J. H. Woo (2004) "Mesophilic and thermophilic temperature co-phase anaerobic digestion compared with singlestage mesophilic- and thermophilic digestion of sewage sludge" Water Environmental Research, 38(7), 1653.

Sorathia, H. S.; P. P. Rathod; and A. S. Sorathiya (2012) "Biogas generation and factors affecting the biogas generation. A review study" International Journal of Advanced Engineering Technology. Vol.III (III) July-Sept, 72-78.

Steffen, R.; O. Szolar; and R. Braun (2000) "Feed stock for anaerobic digestion. Making energy and solving modern waste problem" Available at: www.adnett.org (accessed 16 September, 2011).

Usman, M. A.; O. Olanipekun; and O. A. Ogunbanwo (2012) "Effect of temperature on biogas generation from lignocellulosic substrate" Int. J. Res. Chem. Environ. 2(2): 68-71.

Vindis, P.; B. Mursec; M. Janzekovic and F. Cus (2009) "The impact of mesophilic and thermophilic anaerobic digestion on biogas production" J. of Ach in Mat and Manu Eng. 30 (2): 192.

Zhao, C. (2011) "Effect of temperature on biogas production in anaerobic treatment of domestic wastewater" UASB System in Hammarby Sjöstadsverk, TRITA LWR Degree, Project 11:35.

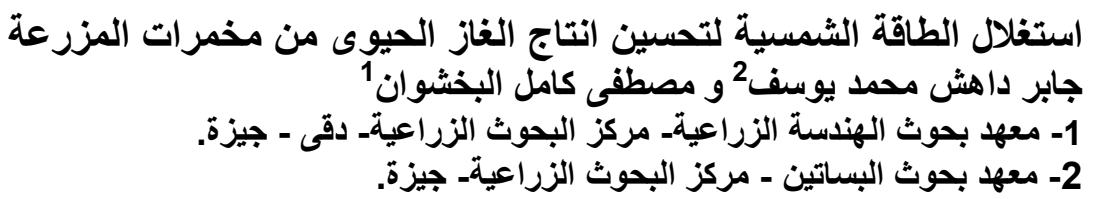

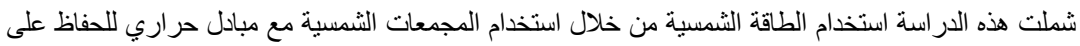

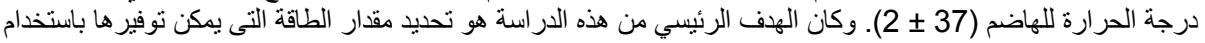

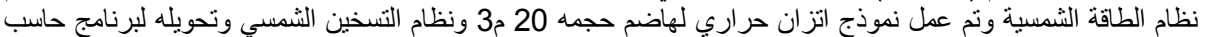

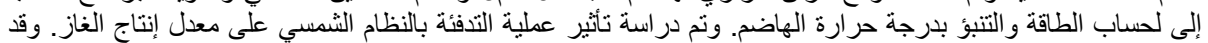

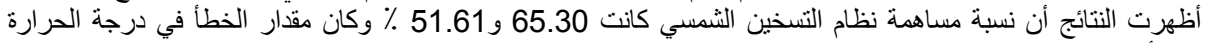

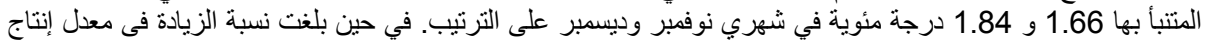

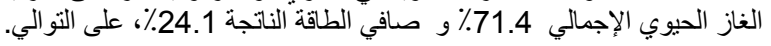

